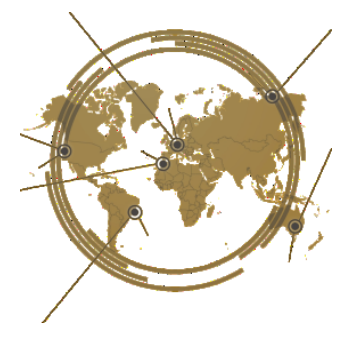

\title{
Low-tech MALL for EFL intensive class among university students in remote areas
}

\author{
Shofiyatul Hasanah ${ }^{1 *}$, Parahita Pradipta ${ }^{2}$ \\ ${ }^{1}$ Madrasah Ibtidaiyah Teacher Education, Islamic Education Faculty, Zainul Hasan Islamic University, Kraksaan, \\ Indonesia, ${ }^{2}$ Master of English Education, Graduate Program, University of Islam Malang, Malang, Indonesia
}

Covid-19 pandemic situation has forced EFL teachers and students to create innovation in online classroom activities. Through a case study at one of private universities in Indonesia, this research aim at exploring the implementation of mobile phone used in learning process in low-tech Mobile-Assisted Language Learning (MALL). The data were collected from observation, in-depth interview, and document review. The findings reveal that mobile phone has an imperative role in concocting student to be full-fledge community, stimulating the feeling of perception, unexceptional mindfulness and teaching of socio-political and social classification. Further, mobile phone and its supporting materials in students' tools rely upon whether there is appropriate security to keep the device, stockpiling of internet data package, wellsprings of electric supply, gracefully of each provider signal, availability to flexibility access in various areas, especially mountainous to remote area. Regarding the challenges, the students experienced multi-layer intricacies: (a) learning facilities including absence of speed data transfer capacity, (b) students' awareness and proficiency in English, and (c) techno pedagogical insight over lecturers. This study implies that enhancement on the student capacity at low-tech level of learning through mobile phone provides meaningful learning assistance, particularly in term of efficiency for classroom activities.

OPEN ACCESS

ISSN 25033492 (online)

${ }^{*}$ Correspondence: Shofiyatul Hasanah

Shoffypradipta99@gmail.com

Received: 7th December 2020 Accepted: 15th April 2021

Published: 19th April 2021

Citation:

Hasanah, S. and Pradipta, P. (2021).

Low-tech MALL for intensive class among university students in remote

areas.

J. Eng. Educ. Society. 6:1.

doi: 10.21070/jees.v6i1.1090
Keywords: Low-tech Mobile Assisted Language Learning; EFL intensive class; remote area

\section{INTRODUCTION}

Mobile learning is working over society into rapid-progressive development. Thusly boundless admittance to a particularly inexpensive and sophisticated device has rather changed the scene of e-learning from various perspectives. Indeed, mobile learning can be considered as the up and coming age of e-learning (Sharples, 2000). Then current day students re-progressively propelled by their own adapting needs, including those emerging from more prominent portability and successive travel. Meanwhile, the production of Android-based mobile phone as a multi-purpose media device was manufactured by various individuals from various countries and companies. 
Simultaneously, it is frequently contended that Androidbased mobile phones are especially fit to supporting social acquaintances and communitarian learning claims that have clear importance-needs for language learning, that mobile technologies were an accustomed portion of the lives of the utmost teacher and student (Facer, 2004). Forbye, the impending age of Information and Communication Technologies (ICT) has acknowledged momentous changes in the structure of teaching devices, by including some new contraptions and changing the wave, better than traditional procedures and strategies. This situation is increasingly needed into paramount whereas Covid-19 pandemic condition is in effect. The classroom management should be adjusted from offline classroom transform into online classroom.

The focus looks to interpret how a few Indonesian EFL lecturers managed complexities they experienced as far as classroom management through MALL for remote area and how much they utilized strategies for taking care of the problematic issues. Then the provided specifics concerning a contextual analysis to divulge the phenomenon since this methodology considers a wide exhibit of depictions of the members' voices, education institution, and procedure in their online classroom confabulate. Until gathered information recently, suggesting common interactive EFL activities in which listening and speaking activities in the situation of online and/or distance learning have been perplexing due to issues of speed bandwidth, audio and visual quality and internet data package amount which is common issue that occurred in Indonesia.

Moving back known history around a few decades ago example, the Open University of Indonesia have tended to this issue by dispersing sound tapes or audio CDs of prerecorded listening materials equipped with printed module as complement document and requesting that students send their own oral recorded on sound tape and written work to lecturers. Then the lecturer checked and returned work, utilizing both printed document and sound tape to give feedback. Consequently, this reflected no direct interaction between lecturers and students and categorized as very lowtech and asynchronous learning concept, in fact this technique cannot be widely applied due to limitation of interactive language learning scope. Henceforth, language learning is, fundamentally, a societal commotion (see Norbrook \& Scott, 2003). Thus, it can be inferred that learning language is actually a social activity between lecturers/teachers to their students.

Deprivation of such activity may be seen as drawbacks. In fact, that Mobile devices are not substitute for existing learning devices, yet they fill in as expansion for learning in new climate having new abilities, however, not all learning substance and exercises are proper for mobile devices. Continuously more, however, interaction linking student to student and connecting students and lecturers in nowadays can be provided by Voice over Internet (VoIP) applications such as (e.g. Yahoo messenger, WhatsApp, Skype, Facebook, Google Meet, Zoom).
Attached by the aforementioned vindication, our aim of study is to investigate the enactment of (1) Low-tech Mobile Assisted Language Learning for English as Foreign Language intensive class among remote area's university student around Probolinggo regency and (2) the enactment of Low-Tech MALL for EFL development at this Private University intensive class. According previously existing research-study intended to classroom management inside Indonesian framework has been formerly supported out by Habibi et al. (2017) who enumerated five evolving matters associated to classroom management, including (1) teachers' mentalities toward new innovation for teaching, (2) schools' scarce paraphernalia, (3) countless students, (4) insignificant rooms, and (5) students' deficient quantities of practice. In addition, Miangah and Nezerat (2012) investigated mobile assisted language learning but the study has yet to specifically focus on foreign language education in remote areas. The research problems of this study are formulated as follow:

(1) How are low-tech MALL applications for EFL students in remote areas used?

(2) How do EFL teachers manage classroom for students in remote areas through low-tech MALL?

\section{Low-Tech MALL-EFL Application for Remote Area's Students}

Mobile learning is undergoing swift evolution whereas it become into Mobile Assisted Language Learning (MALL) but originally it comes from Computer Assisted Language Learning or we called it CALL due to computer technology miniaturization and enhancement. Initial generations of mobile learning developments lean towards to propose officially premeditated activities in mean time there is transformation from CALL to MALL likewise from Personal Computer into Mobile Computer or laptop into computer-like-capability-mobile-phone form, prudently constructed through educators and technologists, and using evolving technologies that were not yet widely reachable-use or well comprehended by ordinary-like people. Recent, all around spread ownership of mobile and wireless device implies that students are progressively in a situation to play the central-role and partake in exercises roused by their own necessities and conditions of utilization, including those emerging from more noteworthy portability and flexibility (Kukulska-Hulme et.al, 2007). Sharples (2006), while previously, mobile learning has regularly been characterized as far as its utilization of portable advancements, later reasoning has foregrounded the mobility of the student. Fallahkhair et al. (2007) characterize the casual parts of mlearning are additionally highlighted. By utilizing AndroidBased mobile phone, Students can take a direct-watch at a film, listen to music or work close by with advanced media utilizing first class instructing assets through internet. 
Moreover, the Android-Based mobile phone gives allowance for the network, for example, the student's shows network that focus on the student giving the amusement and educative capacities like cartoons. These student's shows are intended to stimulate the real characters in the reality and this effectively makes the conditions for learning a similar way oral description and narrating do. Cartoons are meant to teach the children different aspects such as linguistics, numeracy and literacy (Munene \& Mutsotso, 2019). Whereas it could be contended that mlearning nowadays comprises commonly by the application Android-Based mobile phone but actually in fact the use of any mobile learning material, so includes books, audiocassettes, audio-CDs, and portable radios and DVD players as illustration of low-tech-asynchronous m-learning usually occurred in some occasion, meanwhile nowadays focuses on the most current technologies. Trifanova et al. (2004) characterize mobile devices like any gadget that is compact-factor, self-sufficient and unpretentious enough to go with us anywhere in each second.

As admittance to wireless networks grows and responsibility of devices, for example, Android-Based mobile phone that can interconnect through such systems builds, the utilization these sorts of mobile phones to help language learning turns out to be commonly perpetual. Its utilization of individual because of the development of Android operating system by Google. These mobile phones that empower better approaches for new way of learning, emphasizing coherence or immediacy of access and communication across various settings of utilization. As has been spoken out by Laurillard (2007), "a typical m-learning activity could build in more prospects for digitallyfacilitated-site-specific activities, and for ownership and control over what the learners do". Consequently, the learning development in online classroom ought to demand students to always rehearsal and exposure English regularly and the teacher ought to facilitate the students to rehearsal English in the online classroom.

Android-based mobile phone is the perceptible encouragement theory which has its indispensable reason that effective learning happens when the faculties are encouraged. Encouragement of senses is the key factor in education because it provides the language proficiency data in the student's mind that commences the process of acquire opportunities for digitally-facilitated-site-specific knowledge, skills and attitudes specifically for student and for this study of remote area's university student. The application which is apposite on such condition due to limitation of internet speed bandwidth, provider data package give direct impact over high-tech-synchronousaudio-visual-mobile-learning, then researcher observed the fact that lecturers who on this perplexing situation is by using low-tech-synchronous-asynchronous VoIP mobile learning technique by which they use WhatsApp as application media learning instead using high-techsynchronous VoIP application for current available like Google Meet, Zoom or Skype.

\section{Classroom Management in Low-tech MALL}

Basically, classroom management has to do with teacher competence, as Aliakbari and Heidarzadi (2015) asserted that examining teachers' proficiency in dealing with a classroom is urgent. Classroom management including creating a setting, arranging the chair, decorating the class, creating the rule, and communicating the rule to the students. Those are classroom management for the real face-to face teaching in the classroom. However, todays' learning in Covid-19 pandemic is in effect complying lecturers in university to implement the teaching and learning via online. Therefore, this condition demands to manage via online classroom that covers student from broaden background culture and area. Hypothetically, concentrates on classroom management bring about a few viewpoints concerning the organization of classwork, for example, associations with parents, showing materials, overcapacity classrooms, seating plans, commotion, and social exercises (Macías 2018).

The purpose is that teacher teaching-proficiency in the class and measures used to deal with the class performance has a critical function especially during running mobile learning under concept of online class in impacting the accomplishment and learning of student. Along this study, the use of Android-Based mobile phone in the online classroom attempted to-be shown in teaching-learning scheme probably close to naturalistic setting and by including the convenience of the undertaking of EFL learning process in the state of university student in which Introducing cases for student and giving the task of comprehending those cases gives a likely to-be naturalistic setting to the mobile learning concept area. However, to deal with the class well, it is needed to comprehend early the three foremost ranges of classroom management: instructional management, people management and behavior management. In addition, Martin et. al (2016), these three measurements collaborate to outline teacher's classroom management styles and guide entirely endeavors to reach proper instructional destinations.

Moreover, Martin et al. (2016) defines three different kinds of classroom management: Instructional management including all aspects: administer seat work, establishing quotidian sequences, and dispensing material, whereas the people management relate to what teachers have faith in about students as an individual and what teachers do to increase their relationship. Meanwhile, the behavior management dimension focuses on pre-planned effort to avert misbehavior moderately than the teachers respond to it. Hence, Martin et. al (2008) adds their clarification that in this feature including building up principles, framing a prize construction, and giving junctures for student input.

By the side of that, the creating task with the cases for online classroom likewise makes more challenging and perplexing for the unexperienced lecturers but the applicability of lecturer's task for resulting direct guidance on assessment models for learning methodologies is under trial and error process, so student may discover mobile learning more burdensome and tough. Overlooking of the 
availability of Android-Based mobile phone and internet connection in the online classroom construct easier MALLEFL process for students to access various English language learning videos which also allow students to learn autonomously through another High-Tech internet content such as YouTube. Autonomous learning refers to student's ability to take control of his or her own learning (Khotimah, et al, 2019). In his case, students can do rehearsal the material after the online class.

\section{Current Condition of Student on Remote Areas while Running Low-Tech MALL for EFL}

The importance of Android-Based mobile phone as multipurpose media devices in guidance of mobile-learning is that we live in an audio-visual device era which infers that having the ability to use audio-visual is paramount. Audiovisual aids are critical mechanical assemblies for EFL learning assessment. It makes the lecturers present the activity effectively and student learn, hold the thoughts better and for huge time span. It helps with taking out modified works thoughts through visual presentation.

Base on this purpose, it is paramount to develop CALL which is evolved into MALL through Computer Mediated Course (CMC) whereas Android-Based mobile phone nowadays has computer-like capability by its Android operating system for enhancing skills among teacher, since students are not only required to interrelate with their friends and teachers in the class, nevertheless likewise, they will interrelate with the people over the world through AndroidBased mobile phone whereas is connected to internet. Anyway, it is expected to follow student's thinking-realm of the implication of what tails we endeavor to address continuing investigations in research on lecturer's instruction for CALL to MALL through CMC-based EFL language learning and a mixture of methodological theories, a changing from old-fashioned which is class attended learning into online language learning in these Covid-19 pandemic days.

Fallahkhair et. al, (2007) extend the use of web-enabled mobile phones, unfolding the advance of a cross-platform method via mobile phones and collaborative television for casual language learning, at variance of that, while mobile devices have the funds for a widespread variability of individual activities and learning on-the-move, they are less influential for enabling learning as of authentic and immersive content. The responsibilities scrutinize of this issue is relevant for both fledgling and experienced partners while send off on EFL learning with ICT based both in more orthodox-ordinary classroom circumstance transforms into online classroom only settings alongside use of AndroidBased mobile phone as conducive learning environment device. Mistar (2012) proposes a conducive learning environment for the students to provide opportunities for the students to learn and acquire communicative competence in both classroom environment and natural environment (outside the classroom). Nevertheless, Natural Environment in Indonesia is limited, considering English is as foreign language and is imparted as essential subject preparatory averagely around from first to fifth semester by non-English major subject. If there is any, it is as non-proportionate exchange, for example, radio stations or TV programs that could enhance student proficiency through this Covid-19 pandemic is very helpful.

Consequently, it is needed to create artificial-natural environment that gives English exposure to the students and enhancing social interaction and communication in English (Pradipta, 2020), in this case through Android-Based mobile phone. Today the main fact by teacher in enabling online language learning reliant on the proficiency to take over the affordances of any given device in this study is Android-Based mobile phone. The potentials and restrictions intended for making meaning and communiqué offered by the available modes (Hampel, 2006) and the capacity to exercising these as per the student's requirements, task requests, and chosen learning conclusions, is generally recognized. In reality, if technology is synchronized into pedagogical performs in a self-assertive style, or, whenever exercised inadequately according to this study which student in remote areas especially around mountainous region around Probolinggo regency is lack of speed bandwidth and internet data package affecting their synchronous audiovisual material during m-learning, their authentic supplementary advantages to language learning possibly will be very unsatisfactory, if not extraordinarily defective English proficiency.

Additionally, a lecturer in exercising a remote area student may have exertion handling online-classroom activities in their lessons. Many lecturers, as the drawback in this study, did not obtain any training on pedagogical CALL-MALL and CMCbased language to teach effectively. Concurrently, some lecturers premeditated their personal learning materials. Thus, the significance of satisfactory-level of training designed for CALL and CMC-based language teaching well-versed by pedagogical contemplations and reasonable hypothetical frameworks (Guichon \& Hauck, 2011). However, to tackle such perplexing issue most lecturers acquiring low-tech asynchronoussynchronous media like WhatsApp due to its flexibility in switching mode from synchronous to asynchronous while it doesn't need a complexity for example high bandwidth and internet data package usage during use on for example Google Meet or Zoom. Rahmadi and Istiqamah (2016) discovered that the hole in educational quality between far off territories and metropolitan urban communities is outrageous. Then instituted by Yamaguchi (2005) a computer is superior to a mobile phone or taking care of different kinds of data like visual, sound, and literary data, yet the mobile phone is improved than a computer in convey ability.

\section{METHODS}

The research project utilized in this investigation is qualitative case study; consequently, the researchers gathered the data by direct observation, in-depth interviewing and document review (Creswell, 2012; Elliott, 2005; Johnson \& Christensen, 2008; Miles, Huberman, \& Saldaña, 2013; O’Donoghue \& Punch, $\underline{2003}$. 
In order to explore the EFL online classroom management of intensive class, this intensive class is additive program that employed on first and second semester in purpose enhancing student English proficiency outside English major to be more prepared for nowadays globalization era. Creswell (2012) asserted that case studies are generally conducted to explore situated phenomena in natural settings. The current study fixated on discovering the MALL-EFL online classroom management of intensive class activity especially the lecturers that have remote areas student around Probolinggo, including problems and solving strategies at one of private university in that area. Next, we introduce the five contributors, with pseudonyms for anonymity.

\section{Contributors Enlisting Process}

Preceding to instigation the study, we obtained permission from the Center of Foreign Language Studies (PSBA) one of Private University in Probolinggo, Indonesia. The advantage position is the first researcher as the director of PSBA and the second is graduated student from Master of English Education at Private University in Malang. The learning institution selected depended on deliberate examining with advantageous methodology. This sampling procedure was used to access the existing data with ease (Cresswell, 2012). Concerning research ethics, the contributors were enquired to recite comprehensively, and mark a consent procedure that designated they enthusiastically volunteered their period for this study, and they also kept back the right to pull out their contribution in at all stages of this study. The contributors elaborate in this study were five English lecturers from the same learning institution. Their names were created into the pseudonyms Cloud, Barret, Tifa, Aerith and Yufi (see Table 1).

\section{Data Collection}

The data were collected through observation, semistructured interview and documentation, started from Covid-19 Pandemic situation in effect around March 2020. Observation is conducted to know the atmosphere of the class via WhatsApp involve interaction and communication between lecturers and students while online learning. In addition, Interviews were conducted to get information about how the classroom management is designed, the strength and weaknesses and how to deal with the problem faced during learning. Indonesian language is used while interviews to avoid miscommunication and misunderstanding between interviewer and interviewee. And the last, documentation such as course outline, teaching report and students' evaluation were used to know the overall implementation of low-tech MALL.

\section{Data Analysis}

To analyze the data, we employed pattern coding planned by Miles et. al, (2013). The consequence of observation, interview and documentation were coded constructed on research questions that were associated to subjects and enquiries to accumulate the evidence looked-for. Coding helped in constructing effective labeling and retrieving data processes (Miles et al., 2013). Be that as it may, the outcome of the interviews should be dissected and compared to recognize the similitudes and contrasts, re-read line by line to discover the consistencies and arising subjects just as subtopics among the information (Jati, et. al, 2019; Muyassaroh et.al, 2019). Here, the transcripts were read to obtain the global understanding, then the similar data were organized into one theme based on universal view of interview result. In data grouping, we selected the most stood out voice in our perspective which closest to the theme.

\section{Trustworthiness}

To ensure the data validity and reliability, the researchers need to do members checks by returning copies of the interview data, findings, and final report to each participant, Lincoln and Guba (1990). This methodology was completed to ensure that every contributor concurred with the information that was extracted from them, which likewise permitted the researchers to utilize the information in the current study.

Table 1 | Contributors' related data

\begin{tabular}{|c|c|c|c|c|c|c|}
\hline No. & Name & Age & $\begin{array}{l}\text { Bachelor's } \\
\text { Degree }\end{array}$ & $\begin{array}{l}\text { Master } \\
\text { Degree }\end{array}$ & $\begin{array}{c}\text { Current } \\
\text { Status }\end{array}$ & Experience \\
\hline 1 & Yufi & 27 & Major & Major & Handle 1 class & $<2$ years \\
\hline 2 & Tifa & 29 & Major & Major & Handle 1 class & $<3$ years \\
\hline 3 & Barret & 55 & Major & Major & Handle 1 class & $<20$ years \\
\hline 4 & Cloud & 31 & Major & Major & Handle 1 class & $<4$ years \\
\hline 5 & Aerith & 28 & Major & Major & Handle 1 class & $<3$ years \\
\hline
\end{tabular}

\section{RESULTS AND DISCUSSION}

\section{Online English Teaching via WhatsApp}

Based on the data collected from observation and interview, the lecturers found some problems in teaching and managing the online class via WhatsApp: (1) Learning facilities in term of speed bandwidth,
Internet data package resulting on defective audio-visual quality, and electricity power supply, (2) students' interest and ability in English, and (3) CALL-MALL-CMC pedagogical insight on lecturers. 


\section{Learning Facilities}

Both offline and online learning need adequate infrastructure level to support the sustainability of the learning. In online learning there are some problem faced by the lecturers in managing the class.

\section{a. Lack of speed bandwidth}

Speed bandwidth is still a problematic for students coming from mountainous area. However, when the speed is low then the students will be slow response and the time allotment will also be delayed. This reflected on Tifa's statement. She said:

Online learning needs more time allotment, if the students are slow response so it delays the time allotment. The learning usually takes one and half hours, sometimes takes three to four hours (Tifa).

Cloud, one of the lecturers also commented on similar condition relate to speed bandwidth, he shared:

When I shared video material to the group, I have to wait for some time to get students' responds and comments toward the video. When I asked the students why they are slow response, they said it due to bad signal condition (Cloud).

Besides, based on the documentation analysis from the teaching report, the first researcher overview proceeding to lecturers' document assessment exhibited that:

The majority of the lecturers start the class on time as schedule but end the class later than it programed before. (first researcher).

Moreover, based on the result of observation conducted by the second researcher on mountainous areas in Kalianan, Pandanlaras, Bermi, Andungbiru, Jangkang, Batur, Kedungsumur and Gunggungan Kidul showed that:

Almost to unviability of signal so when the students join online learning, they come to the nearest village with better signal or even they find free Wi-Fi which is connected to internet through fiber optic (second researcher).

\section{b. Lack of internet data package}

Having online class must be supported with enough internet data package, foronline learning consumes a lot of data package. As Yufi commented on this problem happen to his students in his class, she shared:

When I shared learning video, asked the students to retell video content in English, the students somehow said they couldn't open it because of limited internet quota (Yufi).

In line with Yufi, Aerith is another lecturer participant, commented that even though every student was given a SIM card with 10 GB's study data package it cannot be used effectively. She explained:

All students were given internet packet data 10 GB for academic application purposes such as zoom and google meet, but the students didn't use it because of limited bandwidth or signal in remote area. I teach via WhatsApp that use the regular packet data the students afford by themselves to solve the problem (Aerith).

Furthermore, the researchers analyze the document on the lecturers' teaching report, in the WhatsApp group chatting showed:

Some lecturers actually have already invited the students to participate the learning via Zoom and Google Meet, but majority of students rejected due to the limited signal in the area they live and only a few students equipped with standardized-laptop for executing Video-VoIP application such as Zoom or Google Meet (the researchers).

The problems faced by the lecturers in this present study may be become problem of online learning in general. However, in Pandemic era in effect of Covid-19 demand technology utility. As Livingstone (2012) scrutinized the main-substance of coalesce ICT and the internet in education in universal and its continuity to language teaching and found that (a) it is used to enable the extensive distribution of valuable possessions in both traditional and interactive formulae, affording the means of joint-cooperative learning dispersed over time and place as required and (b) it is enacted for the learning of foreign languages with special educational needs.

c. Dependable on Electricity supply

Using the product of technology is dependable on electricity. When the electricity is off for a long period, it affects the signal and the process of online learning. As Aerith's statement:

It is often happened in my class, when I was teaching and giving instruction to the students, suddenly the electricity was black out, no signal and students becomes slow response (Aerith).

Based on the second researcher direct observation in some areas in Probolinggo, it showed that:

Especially in rainy season it is often blackout inareas like Kalianan, Pandanlaras, Bermi, Jangkang, Batur, Kedungsumur and Gunggungan Kidul. The second researcher minimum stay at one night in those area to find the truth condition (second researcher).

\section{Students' Interest and Ability in English}

The major encounters in MALL-EFL based is the student's awareness and enthusiasm. Students with less mediocre enthusiasm in learning English difficult to comprehend the material. However, online learning somehow quite boring for some students, besides other factors also affect such as lack of vocabulary mastery, lack of confidence make the students did not participate actively in online learning. This situation revealed by Cloud, Tifa and Barret that when they are teaching only students with 
high motivation and good capability in English participate enthusiastically in the learning process, while students with low motivation are lazy to do the task and become unreceptive partaker. It portrayed on their commentaries:

English is as a foreign language in Indonesia, and the students didn't communicate English in their daily. Many students are difficult to pronounce words in English, so they shy and hesitate to speak English via voice recorded message (Cloud).

What the lecturer participant tried to explain is that in countries where English is not spoken as the students' first language (Souriyavongsa et. al, 2013). Since English is not used as regular communiqué, so numerous students think that English is not imperative, and they will not use it in the future. Beside their limitation in English pronunciation, when the lecturers give task and the students should submit it via voice recorded message, the students felt shy and confidence.

When I explain the material in English, I must re-explain it in Indonesian because the students said they didn't understand yet (Tifa).

When I gave a task to students, some of them commented in Madurese's. They said that they didn't know English many times although I give them motivation (Barret).

What the lecturer tried to explain that the students' belief on English affected their thought that English is difficult to master, so it makes students unmotivated to learn English as well as their ability is low. Above and beyond the students more convenient and arrogance to express their native language.

Based on the researchers' document review on WhatsApp group chatting, whereas we work as an admin in second to lecturer but operated silently that is found that:

There are some students has anomaly in psychology condition have an occasion in mocking the lecturer with Madurese language, even tendency to bullying. This somehow degrading the lecturer's psychological condition in teaching and learning process (researchers).

To sum up, the lecturers' problem with students' motivation in learning English in this study corroborate recent studies such as students' low motivation for learning EFL (Liu et. al, 2020), and language barriers between mother tongue and English as a foreign language (Souriyavongsa et. al, 2013). Furthermore, this finding is also confirmed by Sayuri (2016) who conducted 24 challenges in learning English. The study showed that English word pronunciation becomes the most difficult part. These encounters befall for the reason that they did not have character-confidence, were anxious of making faults, knowledgeable shyness around others, felt nervous, were occupy in speaking English and adept infrequently.

\section{CALL-MALL-CMC Pedagogical Insight on Lecturers}

Another of the third encounters in MALL-EFL based is the lecturer's pedagogical insight. For peculiar lecturer with lack of experiences in online learning have contributed perplexing learning situation to understand the material specified to the student. Nevertheless, online learning somehow quite perplexing for lecturer, besides other factors also affect such as lack of ICT mastery, lack of CALL-MALL-CMC pedagogical insight make the lecturer shows their slow response in participating in online teaching learning process. Thus, the significance of satisfactorylevel of training designed for CALL and CMC-based language teaching well-versed by pedagogical contemplations and reasonable hypothetical frameworks (Guichon \& Hauck, 2011). This situation revealed by Barret that he needs an effort to conduct online learning. It portrayed on his commentaries:

Before the pandemic Covid-19, I used to teach the students directly in the classroom but now everything is transforming into a new territory. I have no experience at all in operating technological applications. but the demand continuously increases in online learning due to pandemic issue. (Barret).

What the lecturer tried to explain that online learning is something beyond reach to be mastered. Thus, it is a drawback on a lecturer side about lack convenient in CALLMALL-CMC pedagogical insight might increase difficulties in the future if the lecturer does not want to transform into a better person.

In addition of that, based on the documentation investigation on or after the teaching report under Microsoft Word format which attached the screenshot of learning events via WhatsApp. The first researcher impression over happening situation to lecturers' document assessment exhibited that:

There was an anomaly lecturer had occasion in persisting an old idea of teaching learning to be applied in online learning, even tendency to change the entire online learning theoretical framework over his online classroom. This somehow degrading the student's psychological enthusiasm in teaching and learning process especially the student with less mediocre English proficiency (first researcher).

\section{Lecturers' Solving Strategies}

\section{Solving Lack of Speed Bandwidth and Internet Data Package}

It is definitely right that lecturers in intensive program applying online learning via WhatsApp, considering students' residence in which difficult to get signal and students' internet data package is also limited and the learning process can run synchronously-asynchronously. It is depicted in dialogue with Tifa:

I decided to have online learning via WhatsApp because of the students' residence where internet signal still become problem. Even though they cannot study synchronously, they still able to learn the material shared by the lecturer. they can also ask directly to the lecturer whenever the find difficulties in learning (Tifa). 
In line with Tifa, Yufi, the other lecturer participant described that he shared the material, gave explanation and opened asking question session in WhatsApp group. If the students couldn't access the material, they learn it later after they have good signal. Therefore, the lecturer's participant in this study provide leeway for longer time in submitting assignments. It is depicted by Yufi in her statement:

Before teaching, I prepare learning video and convert the video into smallest size, so the students didn't exert up much quota when downloaded it (Yufi).

On the other hand, Cloud advised the students to ensure they have adequate internet data package before joining the class, as he stated:

Before the class, I constantly prompted my students to preserve their internet quota for the online learning since if they do not have sufficient internet quota, it will disturb their online learning (Cloud).

\section{Dependable on Electricity Solving Strategies}

As discussed previously that the product of technology is dependable on electricity. Therefore, before using the product we have to make sure that the electricity is full. Aerith give preventing solution to her students relate to electricity supply:

I order my students to charge their mobile phone before the class, so even though the electricity is black out the class still go on. Besides having power bank is a good idea in case the battery is off. (Aerith).

\section{Solving Students' Interest and Ability in English}

Every lecturer has different solution for the problems happened in online learning. As Barret and Tifa presented the material in a simple and attractive way. So, the students are interested in the leaning and they can understand the material easily. This strategy is depicted in Barret's and Tifa's narratives:

Giving interesting material and presenting it in simplest way will make students understand the material easily, so they are motivated to learn English more (Barret).

Vocabulary and pronunciation are the major problem happened in my class. So, I select video as learning media. Thus, the students can learn trough the video and re-play it again outside the class hours if they want to learn again. (Tifa).

As Tifa's statement, it can be inferred that the video shared by the lecturer enable students to learn autonomously. Autonomous learning refers to student's ability to take control of his or her own learning (Khotimah, et al., 2019).

\section{Solving with CALL-MALL-CMC Pedagogical Insight on Lecturers}

As mention previously that the problem with CALLMALL-CMC pedagogical insight only happened to a peculiar lecturer with no experience at all in using WhatsApp due to his private reason didn't mean that the lecturer himself didn't want to improvise himself about technology. Barret claimed himself that:

At first, I was inconvenient with online teaching, however I must try hard to learn and to be acquainted with Android-Based mobile phone and some android applications like WhatsApp. Even though, I'm old generation person, I will do best can do (Barret).

Furthermore, in this study, the lecturer participants generally used different learning method and strategy to deal with the problems. They also use diverse learning sources to support their teaching. Based on the document review, it was found that:

In the beginning of teaching some lecturers teach based on their perspective, since it was given course outline covering some guidelines, so the lecturers refer to course outline although use different source of learning but in the same topics. (first researcher).

To sum up, overall, the problems occurred in this study are not a big deal since all lecturer participants tried hard to find solution for every problem they encountered. Having a solid team also make them easier to cope with the problems.

\section{CONCLUSION}

The primary goal of this study is to investigate online classroom management in EFL intensive class with lowtech MALL for students in remote area, including the problems faced by the lecturers and coping strategies they employed.

The problems faced by the lecturers in this study, such as: (a) learning facilities including lack of speed bandwidth, lack of internet data package, and dependable on electricity, (b) Students' interest and ability in English, and (c) Lack of CALL-MALL-CMC pedagogical insight on lecturers. We found that the problem occurred is correlated each other, so it needs to be solved thoroughly.

To anticipate the further impact of pandemic, it is vital for the next future lecturers to have adequate pedagogical, teaching and practice knowledge, such as subject matter, pedagogy, and pedagogical content knowledge, and also teachers' professional digital competencies to support learner motivation and learner autonomy. Furthermore, teachers and students are supposed to be familiar and able to apply technology in their learning, either low-tech or high-tech media.

Practically, this study acclaims that both students and lecturers ought to have acceptable internet data package and ensure the signal availability in their area before going on online learning. Beside that, it needs to identified student's entry behavior and student's learning style, so the lecturer can consider what strategies, methods and media to be applied in their online learning. Moreover, lecturers can use interesting media like video that covers audio (pronunciation) and visual (picture) contents that gives students model of EFL learning and prevent them from boredom. 


\section{ACKNOWLEDGMENT}

We express our gratitude for all contributors for their helpful input on the factual information for this paper. Our appreciation additionally goes to the anonymous person during on site direct observation for encouraging the additive information and enhancing the theoretical framework.

\section{REFERENCES}

Aliakbari, M., \& Heidarzadi, M. (2015). The relationship between EFL Teachers' Beliefs and actual practices of classroom management. Cogent Education, 4(1), $1-13$.

Creswell, J. W. (2012). Educational research: Planning, conducting, and evaluating quantitative and qualitative research (4th ed.). Pearson.

Elliott, J. (2005). Using Narrative in Social Research: Qualitative and Quantitative Research. SAGE.

Facer, K. (2004). Foreword to the literature in mobile technologies and learning, in: (Eds) L.Naismith, P.Lonsdale, G.Vavoula\& M. Sharples Futurelab report 11 .

Fallahkhair, S., Pemberton, L. \& Griffiths, R. (2007). Development of a cross-platform ubiquitous language learning service via mobile phone and interactive television. Journal of Computer Assisted Learning, 23(4), 312-325.

Guichon, N. \& Hauck, M. (2011). Teacher education research in CALL and CMC: More in demand than ever. ReCALL. 23(3), 187-199.

Habibi, A., Mukminin, A., Sofwan, M., \& Sulistiyo, U. (2017). Implementation of classroom management by English teachers at high schools in Jambi, Indonesia. Studies in English Language and Education, 4(2), 172-189.

Hampel, R. (2006) Rethinking task design for the digital age: A framework for language teaching and learning in a synchronous online environment. ReCALL, 18(1): 105-121.

Jati, A. F., Fauziati, E., \&Wijayanto, A. (2019). Why do the students do disruptive behavior in english classroom? A case study on senior high school students in one of the small town in Indonesia. International Journal of Language Teaching and Education, 3(2), 130-141.

Johnson, B., \& Christensen, L. (2008). Educational research: Quantitative, qualitative, and mixed approaches (3rd ed.). Sage Publications, Inc.

Khotimah, K., Widiati, U., Mustofa, M., \&Ubaidillah, M. F. (2019). Autonomous English learning: Teachers' and students' perceptions. Indonesian Journal of Applied Linguistics, 9, 371-381.

Kukulska-Hulme, A., Traxler, J. \& Pettit, J. (2007). Designed and user-generated activity in the mobile age, Journal of Learning Design, 2(1), 52-65.

Laurillard, D. (2007). Pedagogical forms of mobile learning: Framing research questions. In
Pachler, N. (ed.) (2007) Mobile learning - Towards a Research Agenda. 153-175. WLE Centre, Institute of Education, University of London.

Lincoln, Y. S. \& Guba, E. G. (1990). Judging the quality of case study reports. International Journal of Qualitative Studies in Education, 3(1), 53-59.

Liu, Y., Hau, K. T., Liu, H., Wu, J., Wang, X., \& Zheng, X. (2020). Multiplicative effect of intrinsic and extrinsic motivation on academic performance: A longitudinal study of Chinese students. Journal of personality, 88(3), 584-595.

Livingstone, S. (2012). Critical reflections on the benefits of ICT in Education. Oxford Review of Education, $38(1), 9-24$.

Macias, D. F. (2018). Classroom management in foreign language education: An exploratory review. Profile: Issues in Teachers' Professional Development, 20(1), 153-166.

Martin, N. K., Schafer, N. J., McClowry, S., Emmer, E. T., Brekelmans, M., Mainhard, T., \& Wubbels, T. (2016). Expanding the definition of classroom management: Recurring themes and new conceptualizations. Journal of Classroom Interaction, 31-41.

Miangah,T. M and Nezarat, A. (2012). Mobile Assisted Language Learning. International Journal of Distributed and Parallel System (IJDP). 3(1).

Miles, M. B.s, Huberman, A. M., \& Saldana, J. (2013). Qualitative Data Analysis: A Method Sourcebook (3rd ed.). Arizona State University.

Mistar, J. (2012). Creating environment conducive to English learning. Language-Edu. 1(1).

Munene, T. S. and Mutsotso, S. N. (2019). Kibabii university use of television in promoting teaching and learning in schools. British International Journal of Education and Social Sciences. 6(5).

Muyassaroh, M. N., Asib, A., \&Marmanto, S. (2019). The teacher's beliefs and practices on the use of digital comics in teaching writing: A qualitative case study. International Journal of Language Teaching and Education, 3(1), 45-60.

Norbrook, H., \& Scott, P. (2003). Motivation in mobile modern foreign language learning. In (Eds.), J.Attewell, G. Da Bormida, M. Sharples, \& C. SavillSmith MLEARN 2003: Learning with mobile devices. pp.50-51. London: Learning and Skills Development Agency.

O’Donoghue, T. A., \& Punch, K. F. (2003). Qualitative Educational Research in Action: Doing and Reflecting. Routledge.

Pradipta, P. (2020) Basic interpersonal communicative skill among students in junior high school. Language-Edu. $9(2)$.

Rahmadi, A., \& Istiqamah, I. (2016). Education in remote areas from teacher's perspective: A case study of East Kalimantan, Indonesia. In Z. Sakhiyya, I. M. A. Arsana\& M. Rahmadewi (Eds.), Education counts (pp. 1-25). Perhimpunan Pelajar. 
Sayuri, S. (2016). Problems in speaking faced by EFL students of mulawarman university. Indonesian Journal of EFL and Linguistics, 1(1), 47-61.

Sharples. M. (2000). The design of personal mobile technologies for lifelong learning. Computers \& Education, 34(3-4), pp. 177-193.

Souriyavongsa, T., Rany, S., Abidin, M. J. Z., \& Mei, L. L. (2013). Factors causes students low english language learning: A case study in the national university of Laos. International Journal of English Language Education, 1(1), 179-192.

Trifanova, A., Knapp, J., Ronchetti, M., \&Gamper, J. (2004). Mobile ELDIT: Challenges in the transitions from an e-learning to an m-learning system. Trento, Italy: University of Trento.

Yamaguchi. T. (2005). "Vocabulary learning with a mobile phone. In Program of the $10^{\text {th }}$ Anniversary Conference of Pan-Pasific Association of Applied Linguistics. p.57.
Conflict of Interest Statement: The authors declare that the research was conducted in the absence of any commercial or financial relationships that could be construed as a potential conflict of interest.

Copyright (C) 2021 Shofiyatul Hasanah and Parahita Pradipta. This is an open-access article distributed under the terms of the Creative Commons Attribution License (CC $B Y)$. The use, distribution or reproduction in other forums is permitted, provided the original author(s) and the copyright owner(s) are credited and that the original publication in this journal is cited, in accordance with accepted academic practice. No use, distribution or reproduction is permitted which does not comply with these terms. 